\title{
接触モード遷移を伴うマニピュレーションのダイナミクス
}

\author{
八島 真 人* 山口秀 谷*
}

\section{Dynamics for Manipulation with Contact Mode Transitions}

Masahito Yashima* and Hideya Yamaguchi*

\begin{abstract}
We propose a novel complementarity model for a general three-dimensional manipulation system with the transitions of contact modes (rolling, sliding and breaking contact points) to solve the forward dynamics problem. The key idea is to construct a dynamic model with contact dynamics and to derive complementary constraints for a rolling contact by decomposing the tangential properties. We also present the $\epsilon$ xistence and uniqueness of a solution to the model, and propose algorithms for solving the problem. We show examples of computer simulation for dynamics of multi-fingered hand manipulation and discuss how the transition of contact modes varies according to the magnitudes of the friction coefficient and the applied joint driving torques.
\end{abstract}

Key Words: Robot Hand, Manipulation, Complementarity Problem, Contact Dynamics, Rolling, Sliding

\section{1.はじめに}

多指ハンドによる操り系を考えた場合, 対象物は多指ハンド と複数の接触点をもち, 能動的に制御される多指ハンドの運動 に順応して対象物の運動が受動的に決定される. 対象物と多指 ハンド間の力の伝達は接触点を通して行われ, 接触点での運動 (転がり, 滑り, 離脱) を発生させる。したがって, 滑りや転が りを利用した操りの運動計画 [19] や制御シミュレーション [16] を行う場合, 関節駆動力の作用によって起こる接触状態の恋化 を推定できる動力学モデルが必要となる。このことは, 接触ダ イナミクス自体のより深い理解が本質的に重要であり, その接 触ダイナミクスを含めた操り系の動力学モデルの構築が必要と なる．滑りや転がりを利用した指先把握 [2] [3] [14] [20] や包み 込み把握 [8] [17]による操り制御則, 逆動力学問題に関する研 究は数多くある.しかし筆者の知る限り，接触モード（転がり， 滑り, 離脱）の遷移を考慮した順動力学問題に関する研究はな い.したがって，従来提案されてきた多くの制御則では，関節の 駆動入力に対して実際に目標の接触モード, 対象物加速度が発 生できるかどうかは厳密には保証されない，本論文では，接触 モード遷移を伴うマニピュレーション理論の構築を目指し, 接 触ダイナミクスを考慮した新たな順動力学モデルを提案する。

マルチボディダイナミクスの理論研究 [1] の観点から, 一般 的な多剛体系の接触ダイナミクスに関して研究が行われている. 本研究はこの分野で得られた知見を利用する．まず，接触ダイ

\footnotetext{
原稿受付 2003 年 2 月 24 日

*防衛大学校

*National Defense Academy
}

ナミクスのカ学モデルとして提案されているコンプライアンス モデルと相補性モデルの概要を示し，その問題点を説明する.

コンプライアンスモデルは，接触する二つの剛体物体の間に 仮想的なコンプライアンスを仮定し，それによって発生する力 を接触力とする方法である，接触力が接触点の相対位置, 相対 速度に関する連続関数で表されるので, 後述の相補性モデルと は異なり, 外力に対して接触力, 加速度が唯一に定まる。した がって, 剛体接触問題ではこのモデルを用いて解析される場合 が多かった [6] [7] [9]. しかし特に三次元の場合, 物理現象を正 しく表すコンプライアンスモデルの構築およびコンプライアン スの同定は非常に困難である。また，接触点の弾性変位を表す 変数を各接触点において導入する必要があるため, 操り系の状 態変数は増大する.さらにサンプリングタイムを小さくしない と数值計算上解が収束しないなどの問題点がある.

相補性モデルは, 剛体物体間の接触点における相対加速度と それに対応する接触力の間に成り立つ関係式を線形相補性問題 に帰着させる解法である. 2 物体間が初期状態で接触している 場合, 相対加速度 $a_{i}$ と接触力 $f_{i}$ の間には, 次の瞬間接触が維 持される場合 $\left(a_{i}=0\right)$ 接触力が非ゼロとなり $\left(f_{i} \geq 0\right)$, 一方接 触が離脱する場合 $\left(a_{i} \geq 0\right)$ 接触力はゼロとなる $\left(f_{i}=0\right)$ とい う相補性が成り立つ.この関係は $n$ 個の接触点に対して, 相補 性制的式（1）で表される。一方, 全剛体系の物体間の相対運動 を表す運動学拘束条件式とダイナミクスを表す運動方程式から, 相対加速度と接触力に関して線形方程式（2）を得る.

$$
\begin{aligned}
a_{i} f_{i}=0, a_{i} & \geq 0, f_{i} \geq 0, \text { for } i=1, \cdots n \\
\boldsymbol{a} & =\boldsymbol{A} \boldsymbol{f}+\boldsymbol{b}
\end{aligned}
$$

ただし, 正方行列 $\boldsymbol{A} \in \Re^{n \times n}$ とべクトル $\boldsymbol{b} \in \Re^{n}$ は, 多剛体 


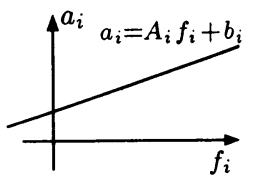

(a)

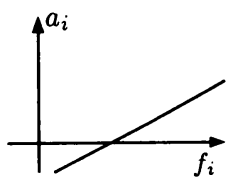

(b)

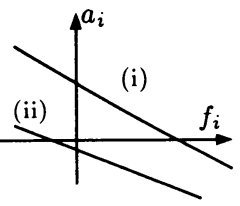

(c)
Fig. 1 Linear complementarity problem

系のコンフィギュレーションと動力学パラメータの値によって 定まる。このとき線形相補性問題とは, 式 (1)，(2) を満たす ベクトル $\boldsymbol{a}, \boldsymbol{f}$ を見つける問題である [4]. 簡単な例として, 2 物体の剛体接触問題を考えよう。この場合線形相補性問題の解 は, 一次方程式 $a_{i}=A_{i} f_{i}+b_{i}$ と正の $a_{i}, f_{i}$ 軸との交点で表さ れる。したがって，Fig.1 (a) の場合接触離脱，(b) の場合接触 維持となる.しかし (c) に示すように 1 次方程式が (i)または (ii) で表される場合, 相対加速度と接触力に関して唯一な解が存 在しない.このように，相補性モデルは力学的に妥当な解が得 られない場合があることに注意しなければならない。これまで 提案されてきた相補性モデル [10] [13] は二次元問題に限定され， その解の力学的妥当性に関する議論が十分されていなかった。

本研究では三次元への拡張性と計算安定性の観点から, 相補 性モデルによる定式化を考える。しかし，上述の理由からマ二 ピュレーションの動力学シミュレーションに適用できるところ まで整備されていない. 本論文ではこれらの問題点を克服した 新たな相補性モデルとその動力学計算アルゴリズムを提案する. 第 2 章では, 操り系の相補性モデルを導出するために必要なクー ロン摩擦モデル，運動拘束およびダイナミクスに関する基礎式 を導出する．第 3 章では，まず転がり接触の接線方向の性質の 分解と変数変換によって，転がり接触の相補性制約式の導出に ついて述べる。この導出法が，三次元操り系の相補性モデルの 定式化を容易にさせている。この定式化をもとに三次元操り系 の剛体接触問題に対する相補性モデルを提案する。ささらに唯一 解の存在性について議論し, 動力学計算アルゴリズムについて 述べる。第 4 章では，実際に提案した相補性モデルを用いて， 多指ハンドによる操りの動力学シミュレーション例を示す.

\section{2. 操り系の剛体接触問題}

本章では Fig. 2 に示すような三次元操り系において，ある瞬 間の操り系の状態に対して関節駆動トルクを作用させたときに, 対象物と多指ハンドの相互作用によって生じる対象物瞬間加速 度, 接触力, 接触モード遷移を推定する問題を解くための基礎 式を導出する。ここでは, 対象物と多指ハンドは剛体と仮定し, また, 全関節数 $n_{\theta}$ の多指ハンドの各指リンクは対象物とたか だか一つの接触点で点接触し, 各関節は一自由度回転関節をも つとする，定式化される操り系は, 関節駆動トルクを作用させ た瞬間に新たな接触が生じない把握コンフィギュレーションに あると仮定し, 全接触点数 $n_{c}$ 個のうち転がり接触, 滑り接触 をそれぞれ $n_{R}, n_{S}$ 個もつとする. 右下添え字 $R, S$ はそれ ぞれ転がり接触, 滑り接触を示す。対象物と指リンクの運動に 伴って两物体上を移動する各接触点には, 各瞬間において対象 物内向き法線方向および接触平面を張り直交する二つの接線方 向を軸とする接触点座標系を設け, それぞれ $N, T, U$ とする.

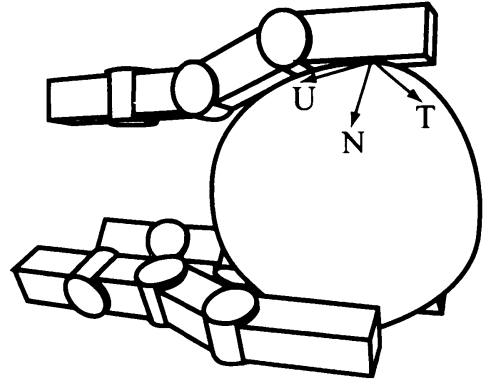

Fig. 2 Multi-fingered hand manipulation

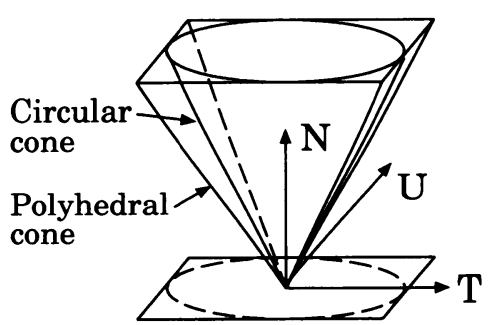

Fig. 3 Friction circular cone and polyhedral cone model

\section{1 クーロン摩擦}

クーロンの法則によれば, Fig. 3 に示すように対象物と指り ンクの $i$ 番目の接触点における接触力は, その接触点を頂点とし

$$
\sqrt{f_{T i}^{2}+f_{U i}^{2}} \leq \mu f_{N i}
$$

で表せる摩擦円錐内または表面上に存在する． $f_{N i}, f_{T i}, f_{U i}$ は指リンクによって対象物に作用する接触力のうち, $i$ 番目の 接触点座標系の $N, T, U$ 方向の接触力成分を示す. ここで $\mu$ は摩擦係数を示す.

さて, 接触力と接触点相対速度, 相対加速度の関係を考える. 接触点座標系で表した $N, T, U$ 方向の相対速度, 相対加速度を $\boldsymbol{v}_{i}=\left[v_{N i}, v_{T i}, v_{U i}\right]^{T}, \boldsymbol{a}_{i}=\left[a_{N i}, a_{T i}, a_{U i}\right]^{T}$ で表す. まず, 接触法線方向の関係式を導出する. 接触点では接触法線方向の 相対速度は $v_{N i}=0$ を満たしている. 一方, 接触法線方向の接 触力と相対加速度には次の不等式制約条件が成り立つ.

$$
a_{N i} \geq 0, \quad f_{N i} \geq 0
$$

この式は，剛体同士の接触では弾性変形がなく，ハンドが対象 物に作用する接触力は圧縮力であることを示す。さて現在の接 触点が次の瞬間も接触が維持される場合, $a_{N i}=0, f_{N i} \geq 0$ と なる。一方，接触が破れる場合， $a_{N i} \geq 0, f_{N i}=0$ となる.す なわち接触法線方向の接触力と相対加速度の間には, $a_{N i}=0$ または $f_{N i}=0$ が成り立つことを示しており，これを相補性と 呼ぶ.この条件は, 転がり接触, 滑り接触ともに成り立つので, 接触法線方向の接触力と相対加速度の間には, 次の相補性条件 が成り立つ。

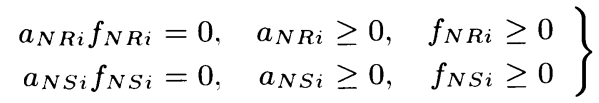

Fig. 4 は式（5）に示す法線方向の接触力と相対加速度の関係 を図示したものである，相補性が成り立つ場合，頂点が直角を 


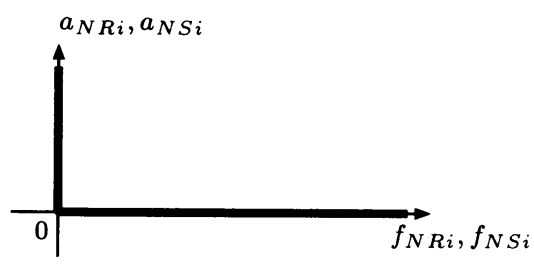

Fig. 4 Complementarity for contact force and relative acceleration in the normal direction

なす二つの半直線からなる L 型形状となることが分かる.

次に接触接線方向の関係式を，滑り接触と転がり接触につい てそれぞれ導出する．接線方向の相対速度が非ゼロすなわち $v_{T i}^{2}+v_{U i}^{2} \neq 0$ ならば滑り接触となる. 接触力は摩擦円錐表面 上に存在し対象物のハンドに対する相対運動を妨げる方向に作 用する.すなわち, 接触点座標系に対する $T, U$ 方向の接触接 線力は

$$
f_{\bullet S i}=\tilde{\mu}_{\bullet i} f_{N S i}, \quad \text { for } \bullet \in\{T, U\}
$$

となる、ただし, $\tilde{\mu}_{\bullet i}=\frac{-\mu v_{\ell}}{\sqrt{\left(v_{T i}\right)^{2}+\left(v_{U i}\right)^{2}}}$.

一方，接線方向の相対速度がゼロすなわち $v_{T i}=v_{U i}=0$ の 場合, 転がり接触となる。転がり接触から滑り接触への遷移の 可能性を検討する場合, 法線方向の関係式と同様に相対加速度 を考慮する必要がある．転がり接触が維持される場合，接触点 接線方向の相対加速度はゼロすなわち $a_{T R i}=a_{U R i}=0$ を澫 たす。この場合, 接触力は摩擦円錐内部に存在する任意の大き さと方向を有する。一方, 転がり接触から滑り接触へ遷移する 場合，相対加速度が発生し， $a_{T R i}^{2}+a_{U R i}^{2} \neq 0$ を満たす．接触 力は摩擦円錐表面上に存在し相対加速度と逆向きの方向に作用 する．以上をまとめると, 転がり接触の接線方向の接触力と相 対加速度の間には次式が成り立つ。

$$
\left.\begin{array}{rll}
\sqrt{f_{T R i}^{2}+f_{U R i}^{2}}<\mu f_{N R i} & \text { for } & a_{T R i}=a_{U R i}=0 \\
f_{\bullet R i}=+\mu f_{N R i} & \text { for } & a_{\bullet R i}<0 \\
f_{\bullet R i}=-\mu f_{N R i} & \text { for } & a_{\bullet R i}>0 \\
& & \text { for } \bullet \in\{T, U\}
\end{array}\right\}
$$

以上，本節では接触法線方向と接触接線方向に関する接触力 と相対加速度に関する関係式として，式 (5)，(7) を導出した。

\section{2 操り系の運動拘束}

転がり接触と滑り接触が混在する多指ハンド操り系の運動拘 束について定式化する。ここで， $\Sigma_{B}$ は基準座標系， $\Sigma_{O}$ は対 象物重心に固定された座標系, $\Sigma_{i j}$ は第 $i$ 指の第 $j$ 番目の接触 点に原点をもち Fig. 2 に示すように $N, T, U$ 方向を軸にもつ 接触点座標系とする。本論文では参照座標系を左上添え字で示 す. $\boldsymbol{x}_{O}, \boldsymbol{R}_{O}$ は基準座標系から見た $\Sigma_{O}$ の位置べクトルと姿勢 を表す回転行列を表す. $\boldsymbol{c}_{O i j}$ は $\Sigma_{O}$ から見た $\Sigma_{i j}$ 原点の位置 ベクトルである.

基準座標系から見た第 $i$ 指の第 $j$ 番目の接触点における相対 速度 ${ }^{B} \boldsymbol{v}_{i j} \in \Re^{3}$ は, 対象物表面上の接触点の速度と指リンク表 面上の接触点の速度の差で与えられ，次式のとおりに表される.

$$
{ }^{B} \boldsymbol{v}_{i j}={ }^{B} \boldsymbol{G}_{i j}^{T B} \boldsymbol{v}_{O}-{ }^{B} \boldsymbol{J}_{i j} \dot{\boldsymbol{\theta}}_{i}
$$

ただし, ${ }^{B} \boldsymbol{G}_{i j}^{T}=\left[\boldsymbol{E}_{3}-\left(\boldsymbol{R}_{O} \boldsymbol{c}_{O i j} \times\right)\right] \in \Re^{3 \times 6}$ は対象物速度. 角
速度 ${ }^{B} \boldsymbol{v}_{O}=\operatorname{col}\left[{ }^{B} \dot{\boldsymbol{x}}_{O}{ }^{B} \boldsymbol{\omega}_{O}\right] \in \Re^{6}$ を第 $i$ 指の第 $j$ 番目の接触点 の対象物表面上の速度に変換する行列, ${ }^{B} \boldsymbol{J}_{i j} \in \Re^{3 \times n_{\theta i}}$ は第 $i$ 指の関節速度べクトル $\dot{\boldsymbol{\theta}}_{i} \in \Re^{n_{\theta i}}$ を第 $i$ 指の第 $j$ 番目の接触点 の指リンク表面上の速度に変換する行列を示す. $n_{\theta i}$ は第 $i$ 指 の関節数, $\left(\boldsymbol{R}_{O} \boldsymbol{c}_{i j} \times\right)$ は $\boldsymbol{c}_{i j}$ の外積と等価な $3 \times 3$ 歪対称行列, $\boldsymbol{E}_{3}$ は $3 \times 3$ 単位行列である. ${ }^{B} \boldsymbol{\omega}_{O}$ は $\Sigma_{O}$ の $\Sigma_{B}$ に対する回 転角速度べクトルである. $\operatorname{col}[$ ] $]$ はかっこ内の要素を縦に並べ た列ベクトルまたは行列を示す。

式（8）を接触点座標系で見た相対速度に変換する， $\Sigma_{O}$ から 見た $\Sigma_{i j}$ の $N, T, U$ 方向の単位ベクトルを $\widehat{\boldsymbol{n}}_{i j}, \widehat{\boldsymbol{t}}_{i j}, \widehat{\boldsymbol{u}}_{i j} \in \Re^{3}$ とすると, $\boldsymbol{R}_{O} \widehat{\boldsymbol{n}}_{i j}, \boldsymbol{R}_{O} \widehat{\boldsymbol{t}}_{i j}, \boldsymbol{R}_{O} \widehat{\boldsymbol{u}}_{i j}$ の転置を式 (8) の左から かけると, 接触点座標系 $N, T, U$ 方向成分の相対速度

$$
v_{\Sigma i j}=\boldsymbol{G}_{\Sigma i j}^{T} \boldsymbol{v}_{O}-\boldsymbol{J}_{\Sigma i j} \dot{\boldsymbol{\theta}}_{i} \quad \text { for } \quad \Sigma \in\{N, T, U\}
$$

を得る。ただし，

$$
\begin{aligned}
\boldsymbol{G}_{N i j}^{T} & =\left(\boldsymbol{R}_{O} \widehat{\boldsymbol{n}}_{i j}\right)^{T}{ }^{B} \boldsymbol{G}_{i j}^{T} \in \Re^{1 \times 6} \\
\boldsymbol{J}_{N i j} & =\left(\boldsymbol{R}_{O} \widehat{\boldsymbol{n}}_{i j}\right)^{T}{ }^{B} \boldsymbol{J}_{i j} \in \Re^{1 \times n_{\boldsymbol{\theta} i}}
\end{aligned}
$$

であり, $\boldsymbol{G}_{T i j}, \boldsymbol{G}_{U i j}, \boldsymbol{J}_{T i j}, \boldsymbol{J}_{U i j}$ も同様に定義される. 式（9）を $m$ 本指すべての接触点についてまとめると

$$
\boldsymbol{v}_{\Sigma}=\boldsymbol{G}_{\Sigma}^{T} \boldsymbol{v}_{O}-\boldsymbol{J}_{\Sigma} \dot{\boldsymbol{\theta}} \quad \text { for } \quad \Sigma \in\{N, T, U\}
$$

を得る。ここで， $\Sigma \in\{N, T, U\}$ とすると

$$
\begin{aligned}
\boldsymbol{v}_{\Sigma} & =\operatorname{col}\left[v_{\Sigma 11}, v_{\Sigma 12}, \cdots, v_{\Sigma m n_{c m}}\right] \in \Re^{n_{c}} \\
\dot{\boldsymbol{\theta}} & =\operatorname{col}\left[\dot{\boldsymbol{\theta}}_{1}, \dot{\boldsymbol{\theta}}_{2}, \cdots, \dot{\boldsymbol{\theta}}_{m}\right] \in \Re^{n_{\theta}} \\
\boldsymbol{G}_{\Sigma} & =\left[\boldsymbol{G}_{\Sigma 11}, \boldsymbol{G}_{\Sigma 12}, \cdots, \boldsymbol{G}_{\Sigma m n_{c m}}\right] \in \Re^{6 \times n_{c}} \\
\boldsymbol{J}_{\Sigma} & =\operatorname{diag}\left[\left[\begin{array}{c}
\boldsymbol{J}_{\Sigma 11} \\
\vdots \\
\boldsymbol{J}_{\Sigma 1 n_{c 1}}
\end{array}\right], \ldots,\left[\begin{array}{c}
\boldsymbol{J}_{\Sigma m 1} \\
\vdots \\
\boldsymbol{J}_{\Sigma m n_{c m}}
\end{array}\right]\right] \in \Re^{n_{c} \times n_{\theta}}
\end{aligned}
$$

であり, $n_{c i}$ は指 $i$ の接触点数, $n_{c}$ は全接触点数, $n_{\theta}$ は全関 節数, $\operatorname{diag}[$ ] はかっこ内の要素を対角にもつ行列を示す.

式（10）に示す相対速度を，それぞれ転がり接触点と滑り接 触点の相対速度べクトル $\boldsymbol{v}_{\Sigma R} \in \Re^{n_{R}}, \boldsymbol{v}_{\Sigma S} \in \Re^{n_{S}}$ for $\Sigma \in$ $\{N, T, U\}$ に分割すると，

$$
\begin{aligned}
& \boldsymbol{v}_{\Sigma R}=\left[\begin{array}{ll}
\boldsymbol{G}_{\Sigma R}^{T} & -\boldsymbol{J}_{\Sigma R}
\end{array}\right]\left[\begin{array}{c}
\boldsymbol{v}_{O} \\
\dot{\boldsymbol{\theta}}
\end{array}\right]=\boldsymbol{W}_{\Sigma R}^{T} \boldsymbol{V} \\
& \boldsymbol{v}_{\Sigma S}=\left[\begin{array}{ll}
\boldsymbol{G}_{\Sigma S}^{T} & -\boldsymbol{J}_{\Sigma S}
\end{array}\right]\left[\begin{array}{c}
\boldsymbol{v}_{O} \\
\dot{\boldsymbol{\theta}}
\end{array}\right]=\boldsymbol{W}_{\Sigma S}^{T} \boldsymbol{V}
\end{aligned}
$$

を得る.ここで， $\Sigma \in\{N, T, U\}$ とすると

$$
\begin{aligned}
\boldsymbol{W}_{\Sigma R}^{T} & =\left[\begin{array}{ll}
\boldsymbol{G}_{\Sigma R}^{T} & -\boldsymbol{J}_{\Sigma R}
\end{array}\right] \in \Re^{n_{R} \times\left(6+n_{\theta}\right)} \\
\boldsymbol{W}_{\Sigma S}^{T} & =\left[\begin{array}{ll}
\boldsymbol{G}_{\Sigma S}^{T} & -\boldsymbol{J}_{\Sigma S}
\end{array}\right] \in \Re^{n_{S} \times\left(6+n_{\theta}\right)} \\
\boldsymbol{V} & =\operatorname{col}\left[\begin{array}{ll}
\boldsymbol{v}_{O} & \dot{\boldsymbol{\theta}}
\end{array}\right] \in \Re^{6+n_{\theta}}
\end{aligned}
$$

であり, $\boldsymbol{G}_{\Sigma R}^{T} \in \Re^{n_{R} \times 6}, \boldsymbol{J}_{\Sigma R} \in \Re^{n_{R} \times n_{\theta}}$ はそれぞれ $\boldsymbol{G}_{\Sigma}^{T}, \boldsymbol{J}_{\Sigma}$ 
の転がり接触に対応した行べクトルをまとめた行列である．滑 り接触点に関して, $\boldsymbol{G}_{\Sigma S}^{T} \in \Re^{n_{S} \times 6}, \boldsymbol{J}_{\Sigma S} \in \Re^{n_{S} \times n_{\theta}}$ も同様に定 義される。

さて, 拘束力によって拘束される相対運動は接触モードに応 じて異なる. 転がり接触点の場合, $N, T, U$ 方向の相対運動が 拘束される。一方, 滑り接触点の場合, $N$ 方向の相対運動が拘 束される. したがって, 拘束される相対運動成分の速度は, 式 (11)，（12）を用いて

$$
\left[\begin{array}{c}
\boldsymbol{v}_{N S} \\
\boldsymbol{v}_{N R} \\
\boldsymbol{v}_{T R} \\
\boldsymbol{v}_{U R}
\end{array}\right]=\left[\begin{array}{c}
\boldsymbol{W}_{N S}^{T} \\
\boldsymbol{W}_{N R}^{T} \\
\boldsymbol{W}_{T R}^{T} \\
\boldsymbol{W}_{U R}^{T}
\end{array}\right] \boldsymbol{V}
$$

で与えられる。相対加速度は, 式（16）の時間微分により

$$
\left[\begin{array}{c}
\boldsymbol{a}_{N S} \\
\boldsymbol{a}_{N R} \\
\boldsymbol{a}_{T R} \\
\boldsymbol{a}_{U R}
\end{array}\right]=\left[\begin{array}{c}
\boldsymbol{W}_{N S}^{T} \\
\boldsymbol{W}_{N R}^{T} \\
\boldsymbol{W}_{T R}^{T} \\
\boldsymbol{W}_{U R}^{T}
\end{array}\right] \dot{\boldsymbol{V}}+\left[\begin{array}{c}
\dot{\boldsymbol{W}}_{N S}^{T} \\
\dot{\boldsymbol{W}}_{N R}^{T} \\
\dot{\boldsymbol{W}}_{T R}^{T} \\
\dot{\boldsymbol{W}}_{U R}^{T}
\end{array}\right] \boldsymbol{V}
$$

で与えられる。ただし, 転がり接触または滑り接触の一方の接 触モードしか存在しない場合，存在していない接触モードに対 応する行が式 (16)，（17）から除かれる。

次に多指ハンド操り系の静力学の釣り合い式を導出する.こ こで, 各転がり接触点, 滑り接触点に作用する接触力の接触点 座標系の $N, T, U$ 方向成分 $f_{\Sigma R i}, f_{\Sigma S i}$ for $\Sigma \in\{N, T, U\}$ をまとめたべクトルを $\boldsymbol{f}_{\Sigma R} \in \Re^{n_{R}}, \boldsymbol{f}_{\Sigma S} \in \Re^{n_{S}}$ とする。 ま た，接触力 $\boldsymbol{f}_{\Sigma R}, \boldsymbol{f}_{\Sigma S}$ と等価な対象物重心に作用する合力・ 合モーメントベクトルを ${ }^{B} \boldsymbol{f}_{O} \in \Re^{6}$, 接触力 $\boldsymbol{f}_{\Sigma R}, \boldsymbol{f}_{\Sigma S}$ の反 力と等価な関節トルクベクトルを $\tau_{H} \in \Re^{n_{\theta}}$ とする.このと き, $\boldsymbol{f}_{\Sigma R}, \boldsymbol{f}_{\Sigma S}, \boldsymbol{f}_{O}, \boldsymbol{\tau}_{H}$ 間の関係式は, 運動学的関係を表す 式 (11)，(12） と仮想仕事の原理から

$$
\begin{aligned}
\boldsymbol{f}_{O}= & \boldsymbol{G}_{N R} \boldsymbol{f}_{N R}+\boldsymbol{G}_{T R} \boldsymbol{f}_{T R}+\boldsymbol{G}_{U R} \boldsymbol{f}_{U R} \\
& +\boldsymbol{G}_{N S} \boldsymbol{f}_{N S}+\boldsymbol{G}_{T S} \boldsymbol{f}_{T S}+\boldsymbol{G}_{U S} \boldsymbol{f}_{U S} \\
\boldsymbol{\tau}_{H}= & -\boldsymbol{J}_{N R}^{T} \boldsymbol{f}_{N R}-\boldsymbol{J}_{T R}^{T} \boldsymbol{f}_{T R}-\boldsymbol{J}_{U R}^{T} \boldsymbol{f}_{U R} \\
& -\boldsymbol{J}_{N S}^{T} \boldsymbol{f}_{N S}-\boldsymbol{J}_{T S}^{T} \boldsymbol{f}_{T S}-\boldsymbol{J}_{U S}^{T} \boldsymbol{f}_{U S}
\end{aligned}
$$

で与えられる。

滑り接触点では式 (6) が成り立つことから, 式 (6) を式 (18),

(19）に代入すると

$$
\begin{aligned}
& \boldsymbol{f}_{O}=\boldsymbol{G}_{N R} \boldsymbol{f}_{N R}+\boldsymbol{G}_{T R} \boldsymbol{f}_{T R}+\boldsymbol{G}_{U R} \boldsymbol{f}_{U R}+\boldsymbol{G}_{\mu S} \boldsymbol{f}_{N S} \\
& \boldsymbol{\tau}_{H}=-\boldsymbol{J}_{N R}^{T} \boldsymbol{f}_{N R}-\boldsymbol{J}_{T R}^{T} \boldsymbol{f}_{T R}-\boldsymbol{J}_{U R}^{T} \boldsymbol{f}_{U R}-\boldsymbol{J}_{\mu S}^{T} \boldsymbol{f}_{N S}
\end{aligned}
$$

を得る。ここで，

$$
\begin{aligned}
\boldsymbol{G}_{\mu S} & =\boldsymbol{G}_{N S}+\boldsymbol{G}_{T S} \tilde{\boldsymbol{\mu}}_{T}+\boldsymbol{G}_{U S} \tilde{\boldsymbol{\mu}}_{U} \\
\boldsymbol{J}_{\mu S}^{T} & =\boldsymbol{J}_{N S}^{T}+\boldsymbol{J}_{T S}^{T} \tilde{\boldsymbol{\mu}}_{T}+\boldsymbol{J}_{U S}^{T} \tilde{\boldsymbol{\mu}}_{U} \\
\tilde{\boldsymbol{\mu}}_{\bullet} & =\operatorname{diag}\left[\tilde{\mu}_{\bullet 1}, \tilde{\mu}_{\bullet 2}, \cdots, \tilde{\mu}_{\bullet n_{S}}\right] \quad \text { for } \bullet \in\{T, U\}
\end{aligned}
$$

である，以上，本節では拘束力によって拘束される相対運動成 分の運動学的関係式 (16),（17）および静力学的関係式 $(20)$, （21）を得た。

\section{3 操り系のダイナミクス} 対象物の運動方程式は,

$$
\boldsymbol{M}_{O} \dot{\boldsymbol{v}}_{O}=\boldsymbol{f}_{O}+\boldsymbol{h}_{O}
$$

で表される.ただし, $\boldsymbol{M}_{O} \in \Re^{6 \times 6}$ は対象物の慣性行列, $\boldsymbol{h}_{O} \in \Re^{6}$ は遠心力・コリオリカ・重力ベクトルを示す. 式 (20) を式 (22) に代入すると，

$$
\begin{aligned}
\boldsymbol{M}_{O} \dot{\boldsymbol{v}}_{O}= & \boldsymbol{G}_{N R} \boldsymbol{f}_{N R}+\boldsymbol{G}_{T R} \boldsymbol{f}_{T R}+\boldsymbol{G}_{U R} \boldsymbol{f}_{U R} \\
& +\boldsymbol{G}_{\mu S} \boldsymbol{f}_{N S}+\boldsymbol{h}_{O}
\end{aligned}
$$

を得る。

指 $i$ の運動方程式は,

$$
\boldsymbol{M}_{H i} \ddot{\boldsymbol{\theta}}_{i}=\boldsymbol{\tau}_{i}+\boldsymbol{\tau}_{H i}-\boldsymbol{h}_{H i}
$$

で表される，ただし， $\boldsymbol{M}_{H i}$ は指 $i$ の慣性行列， $\boldsymbol{\tau}_{i}$ は関節駆動 トルクベクトル， $\boldsymbol{\tau}_{H i}$ は指りンクから対象物に加えられる接触 力の反力に等価な関節トルクベクトル， $\boldsymbol{h}_{H i}$ は遠心力・コリオ リカ・重力ベクトルを示す.

各指の運動方程式（24）を $m$ 本指すべてについてまとめると

$$
\boldsymbol{M}_{H} \ddot{\boldsymbol{\theta}}=\boldsymbol{\tau}+\boldsymbol{\tau}_{H}-\boldsymbol{h}_{H}
$$

を得る。ここで，

$$
\begin{aligned}
\boldsymbol{M}_{H} & =\operatorname{diag}\left[\boldsymbol{M}_{H 1}, \boldsymbol{M}_{H 2}, \cdots, \boldsymbol{M}_{H m}\right] \in \Re^{n_{\theta} \times n_{\theta}} \\
\boldsymbol{\tau} & =\operatorname{col}\left[\boldsymbol{\tau}_{1}, \boldsymbol{\tau}_{2}, \cdots, \boldsymbol{\tau}_{m}\right] \in \Re^{n_{\theta}}
\end{aligned}
$$

であり， $\boldsymbol{h}_{H}, \boldsymbol{\tau}_{H}$ も同様に定義される. 式 (21) を式 (25) に 代入すると，

$$
\begin{aligned}
\boldsymbol{M}_{H} \ddot{\boldsymbol{\theta}}= & \boldsymbol{\tau}-\boldsymbol{J}_{N R}^{T} \boldsymbol{f}_{N R}-\boldsymbol{J}_{T R}^{T} \boldsymbol{f}_{T R}-\boldsymbol{J}_{U R}^{T} \boldsymbol{f}_{U R} \\
& -\boldsymbol{J}_{\mu S}^{T} \boldsymbol{f}_{N S}-\boldsymbol{h}_{H}
\end{aligned}
$$

を得る。

以上より, 式 (23)，(26）をまとめ, 式（13）を用いて表す と, 操り系全体の運動方程式

$$
\begin{aligned}
\boldsymbol{M} \dot{\boldsymbol{V}}= & \boldsymbol{W}_{N R} \boldsymbol{f}_{N R}+\boldsymbol{W}_{T R} \boldsymbol{f}_{T R}+\boldsymbol{W}_{U R} \boldsymbol{f}_{U R} \\
& +\boldsymbol{W}_{\mu S} \boldsymbol{f}_{N S}+\boldsymbol{h}
\end{aligned}
$$

を得る。ここで，

$$
\begin{aligned}
\boldsymbol{W}_{\mu S} & =\operatorname{col}\left[\begin{array}{ll}
\boldsymbol{G}_{\mu S} & -\boldsymbol{J}_{\mu S}^{T}
\end{array}\right], \quad \boldsymbol{M}=\operatorname{diag}\left[\begin{array}{ll}
\boldsymbol{M}_{O} & \boldsymbol{M}_{H}
\end{array}\right] \\
\boldsymbol{h} & =\operatorname{col}\left[\begin{array}{ll}
\boldsymbol{h}_{O} & \boldsymbol{\tau}-\boldsymbol{h}_{H}
\end{array}\right]
\end{aligned}
$$

である. 式 (27) を次章で述べる相補性問題への定式化のため に, 接触力ベクトル $\boldsymbol{f}_{\Sigma R}, \boldsymbol{f}_{\Sigma S}$ の成分 $f_{\Sigma R i}, f_{\Sigma S i}$ for $\Sigma \in$ $\{N, T, U\}$ を用いると, 操り系全体の運動方程式は

$$
\begin{aligned}
\boldsymbol{M} \dot{\boldsymbol{V}}= & \sum_{i=1}^{n_{R}}\left(\boldsymbol{W}_{N R i} f_{N R i}+\boldsymbol{W}_{T R i} f_{T R i}+\boldsymbol{W}_{U R i} f_{U R i}\right) \\
& +\sum_{i=1}^{n_{S}} \boldsymbol{W}_{\mu S i} f_{N S i}+\boldsymbol{h}
\end{aligned}
$$


で書き表される。ここで， $\Sigma \in\{N, T, U\}$ とすると

$$
\begin{aligned}
& \boldsymbol{W}_{\Sigma R i}=\operatorname{col}\left[\begin{array}{ll}
\boldsymbol{G}_{\Sigma R i} & -\boldsymbol{J}_{\Sigma R i}^{T}
\end{array}\right] \in \Re^{6+n_{\theta}} \\
& \boldsymbol{W}_{\mu S i}=\operatorname{col}\left[\begin{array}{ll}
\boldsymbol{G}_{\mu S i} & -\boldsymbol{J}_{\mu S i}^{T}
\end{array}\right] \in \Re^{6+n_{\theta}}
\end{aligned}
$$

は, それぞれ $\boldsymbol{W}_{\Sigma R}, \boldsymbol{W}_{\mu S}$ の $i$ 番目の列ベクトルである.

最後に，本章で導出した操り系モデルを用いて，三次元操り 系の剛体接触問題を以下のように定義する.

定義 1 (三次元操り系の剛体接触問題) 三次元操り系に対し $\tau, \boldsymbol{q}_{O}, \dot{\boldsymbol{q}}_{O}, \boldsymbol{M}_{O}, \boldsymbol{h}_{O}, \boldsymbol{\theta}, \dot{\boldsymbol{\theta}}, \boldsymbol{\tau}, \boldsymbol{M}_{H}, \boldsymbol{h}_{H}$ が与えられたと き, 対象物加速度, 接触力および接触モード遷移を推定するた めに, 式 (5)，（7)，(17)，（29）を満たす $\ddot{\boldsymbol{q}}_{O}, \ddot{\boldsymbol{\theta}}, \boldsymbol{f}_{N R}, \boldsymbol{f}_{T R}$, $\boldsymbol{f}_{U R}, \boldsymbol{f}_{N S}, \boldsymbol{a}_{N R}, \boldsymbol{a}_{T R}, \boldsymbol{a}_{U R}, \boldsymbol{a}_{N S}$ を決定すること.

\section{3. 相補性モデルへの定式化}

\section{1 転がり接触の相補性}

剛体接触では, 接触力と相対加速度の間には式 (5), (7) に示 す関係が成り立つ. 式 (5) は接触法線方向の接触力 $f_{N R i}, f_{N S i}$ と相対加速度 $a_{N R i}, a_{N S i}$ の相補性を示し, 式（1）に示すよ うに定式化できる。一方, 転がり接触の接線方向の関係式を表 す式 (7) は, $a_{T R i}, a_{U R i}, f_{T R i}, f_{U R i}, f_{N R i}$ が未知数である ので非線形式となる。式（7）は

$$
\left.\begin{array}{rl}
-\mu f_{N R i}<f_{\bullet R i}<+\mu f_{N R i} & \text { for } \quad a_{\bullet R i}=0 \\
f_{\bullet R i}=+\mu f_{N R i} & \text { for } \quad a_{\bullet R i}<0 \\
f_{\bullet R i}=-\mu f_{N R i} & \text { for } \quad a_{\bullet R i}>0
\end{array}\right\}
$$

で表される. Fig. 5 は, 式 (30) に示す接線方向の接触力と相 対加速度の関係を図示したものである。その形状は相補性を表 すFig. 4 とは異なり，直角をなす二つの頂点をもつ形状を成す. 本節では, Fig. 5 に示す接線方向の性質を変数変換と分解によっ て, Fig. 4 に示すような L 型形状に分割することで転がり接触 に関する相補性制約式を導出する。

さて, Fig. 5 から分かるように $T, U$ 方向の接触力 $f_{T R i}, f_{U R i}$ と相対加速度 $a_{T R i}, a_{U R i}$ は, その符号によって式 (31) に示 す二つの接触集合 $S_{1}, S_{2}$ のいずれかに属する.

$$
\left.\begin{array}{r}
S_{1}=\left\{f_{\bullet R i}, a_{\bullet R i} \mid\left(\text { i) } a_{\bullet R i}<0 \text { and } f_{\bullet R i}=+\mu f_{N R i}\right. \text { or }\right. \\
\left(\text { ii) } a_{\bullet R i}=0 \text { and } 0 \leq f_{\bullet R i}<\mu f_{N R i}\right\} \\
S_{2}=\left\{f_{\bullet R i}, a_{\bullet R i} \mid\left(\text { i) } a_{\bullet R i}>0 \text { and } f_{\bullet R i}=-\mu f_{N R i}\right. \text { or }\right. \\
\left(\text { ii) } a_{\bullet R i}=0 \text { and }-\mu f_{N R i}<f_{\bullet R i} \leq 0\right\}
\end{array}\right\}
$$

Fig. $6(\mathrm{a})$ は接触集合 $S_{1}, S_{2}$ に属する接触接線方向の接触力 と相対加速度の関係を図示したもので, Fig. 5 を $a_{T R i}, a_{U R i}$ 軸に対して左右に分割したものである。接触集合 $S_{1}, S_{2}$ に属 する $f_{T R i}, f_{U R i}, a_{T R i}, a_{U R i}$ は，それぞれ $S_{1} \ni\left\{0 \leq f_{\bullet R i} \leq\right.$ $\left.\mu f_{N R i}, a_{\bullet R i} \leq 0\right\}, S_{2} \ni\left\{-\mu f_{N R i} \leq f_{\bullet R i} \leq 0, a_{\bullet R i} \geq 0\right\}$ for $\bullet \epsilon$ $\{T, U\}$ を満たす. そこで接触集合 $S_{1}, S_{2}$ の変数を, 非負変数 $f_{T R i}^{+}, f_{T R i}^{-}, f_{U R i}^{+}, f_{U R i}^{-} \geq 0, a_{T R i}^{+}, a_{T R i}^{-}, a_{U R i}^{+}, a_{U R i}^{-} \geq 0$ を導入して変数変換し, 接触集合 $S_{1}, S_{2}$ を式 $(32)$ に示すよ うに再定義する. 非負, 非正の変数 $f_{T R i}, f_{U R i}, a_{T R i}, a_{U R i}$ をそれぞれ右上添え字,+- で示す.

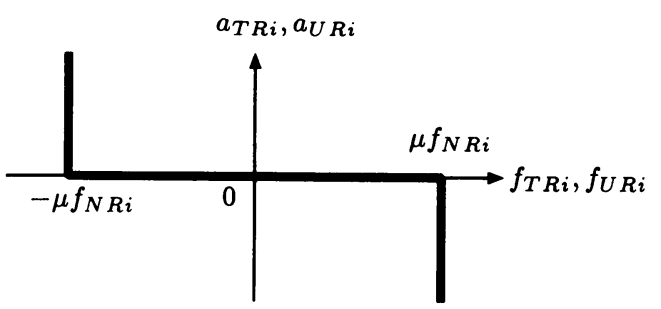

Fig. 5 Relation between contact force and relative acceleration in the tangential direction for polyhedral cone model

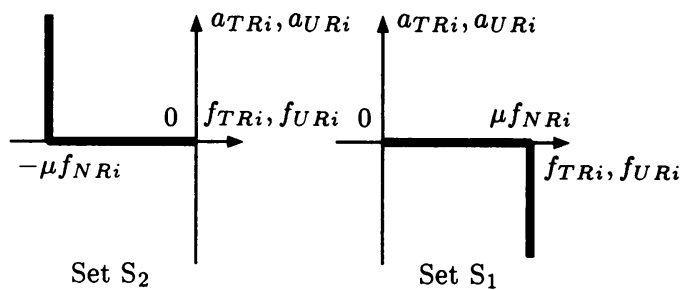

(a)

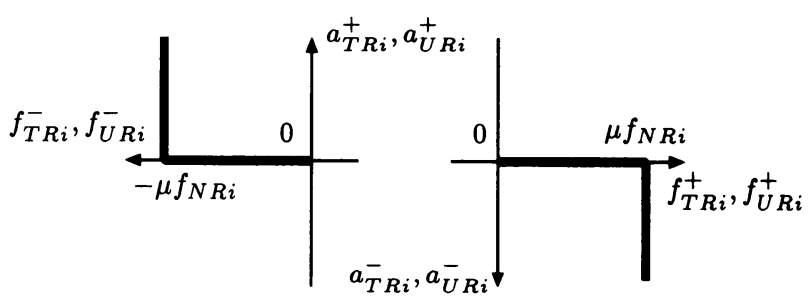

Set $\mathrm{S}_{2}$

Set $S_{1}$

(b)

Fig. 6 Decomposition of tangential characteristics for rolling contact

$$
\left.\begin{array}{r}
S_{1}=\left\{f_{\bullet R i}^{+}, a_{\bullet R i}^{-} \mid(\mathrm{i}) a_{\bullet R i}^{-}>0 \text { and } f_{\bullet R i}^{+}=\mu f_{N R i}\right. \text { or } \\
\left(\text { ii) } a_{\bullet R i}^{-}=0 \text { and } 0 \leq f_{\bullet R i}^{+}<\mu f_{N R i}\right\} \\
S_{2}=\left\{f_{\bullet R i}^{-}, a_{\bullet R i}^{+} \mid(\text {i }) a_{\bullet R i}^{+}>0 \text { and } f_{\bullet R i}^{-}=\mu f_{N R i}\right. \text { or } \\
\left(\text { ii) } a_{\bullet R i}^{+}=0 \text { and } 0 \leq f_{\bullet R i}^{-}<\mu f_{N R i}\right\}
\end{array}\right\}
$$

Fig. 6 (b) は，再定義された接触集合 $S_{1} ， S_{2}$ に属する接触接 線方向の接触力と相対加速度の関係を図示したものである.こ のように接線方向の性質を分解することで, 接触集合 $S_{1}, S_{2}$ がそれぞれお互いに独立な変数 $S_{1} \ni\left\{f_{\bullet R i}^{+}, a_{\bullet R i}^{-} \geq 0\right\}, S_{2} \ni$ $\left\{f_{\bullet R i}^{-}, a_{\bullet R i}^{+} \geq 0\right\}$ で表され，二つの L 型形状に分割することが できることが分かる.

さらに接触接線力に関して

$$
\left.\begin{array}{cc}
f_{\bullet R i}^{+}+\Delta_{\bullet i}^{+}=\mu f_{N R i}, & 0 \leq \Delta_{\bullet i}^{+} \leq \mu f_{N R i} \\
f_{\bullet R i}^{-}+\Delta_{\bullet i}^{-}=\mu f_{N R i}, & 0 \leq \Delta_{\bullet i}^{-} \leq \mu f_{N R i} \\
& \text { for } \bullet \in\{T, U\}
\end{array}\right\}
$$

を満たす非負のスラック変数 $\Delta_{T i}^{+}, \Delta_{T i}^{-}, \Delta_{U i}^{+}, \Delta_{U i}^{-}$を導入す ることで式（32）を整理する. Fig. 7 は Fig. 3 の $N-T$ （また は $N-U)$ 断面に対して，式（33）に示す関係を図示したもの である.ここで $\Delta_{T i}^{+}$と $\Delta_{T i}^{-}\left(\right.$または, $\Delta_{U i}^{+}$と $\left.\Delta_{U i}^{-}\right)$は，それ ぞれ接触接線力 $f_{T R i}^{+}$と $f_{T R i}^{-}$(または, $f_{U R i}^{+}$と $f_{U R i}^{-}$) が摩 擦四角錐の境界に達するまでの余裕を示している。式 (33) の 

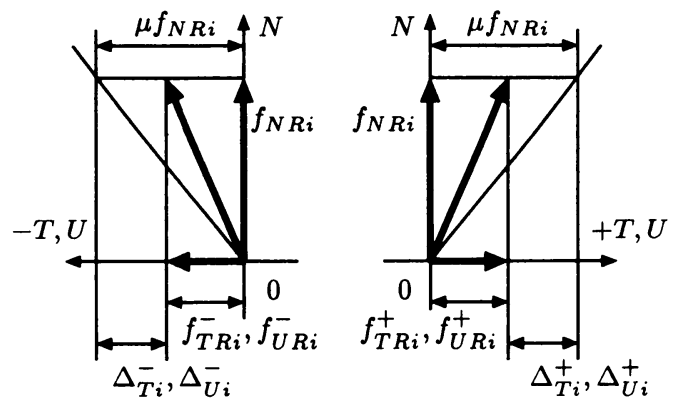

Fig. 7 Slack variables of friction polyhedral cone

$f_{\bullet R i}^{+}$と $f_{\bullet R i}^{-}$を式 $(32)$ に代入すると, 接触集合 $S_{1}, S_{2}$ は

$$
\left.\begin{array}{rl}
S_{1}=\left\{\Delta_{\bullet i}^{+}, a_{\bullet R i}^{-} \mid\right. & \left(\text {i) } a_{\bullet R i}^{-}>0 \text { and } \Delta_{\bullet i}^{+}=0\right. \text { or } \\
& \text { (ii) } \left.a_{\bullet R i}^{-}=0 \text { and } 0 \leq \Delta_{\bullet i}^{+} \leq \mu f_{N R i}\right\} \\
S_{2}=\left\{\Delta_{\bullet i}^{-}, a_{\bullet R i}^{+} \mid\right. & \left(\text {i } a_{\bullet R i}^{+}>0 \text { and } \Delta_{\bullet i}^{-}=0\right. \text { or } \\
& \text { (ii) } \left.a_{\bullet R i}^{+}=0 \text { and } 0 \leq \Delta_{\bullet i}^{-} \leq \mu f_{N R i}\right\}
\end{array}\right\}
$$

で表される. 式（34）は，明らかに $T$ 方向に関して $a_{T R i}^{-}$と $\Delta_{T i}^{+}, a_{T R i}^{+}$と $\Delta_{T i}^{-}, U$ 方向に関して $a_{U R i}^{-}$と $\Delta_{U i}^{+}, a_{U R i}^{+}$と $\Delta_{U i}^{-}$に関する相補性を表しているので,

$$
\left.\begin{array}{rl}
S_{1}=\left\{\Delta_{\bullet i}^{+}, a_{\bullet R i}^{-} \mid\right. & a_{\bullet R i}^{-} \Delta_{\bullet i}^{+}=0, \\
& \left.a_{\bullet R i}^{-} \geq 0,0 \leq \Delta_{\bullet i}^{+} \leq \mu f_{N R i}\right\} \\
S_{2}=\left\{\Delta_{\bullet i}^{-}, a_{\bullet R i}^{+} \mid\right. & a_{\bullet R i}^{+} \Delta_{\bullet i}^{-}=0, \\
& \left.a_{\bullet R i}^{+} \geq 0,0 \leq \Delta_{\bullet i}^{-} \leq \mu f_{N R i}\right\}
\end{array}\right\}
$$

で書き表される. 以上より, 非負の相対加速度変数 $a_{T R i}^{+}, a_{T R i}^{-}$, $a_{U R i}^{+}, a_{U R i}^{-}$と非負のスラック変数 $\Delta_{T i}^{+}, \Delta_{T i}^{-}, \Delta_{U i}^{+}, \Delta_{U i}^{-}$を 導入することによって, 転がり接触の接線方向に関する相補性 制約式（35）を導くことができた。

\section{2 相補性モデル}

本節では, 三次元操り系の相補性モデルを導出するために, 相補性制約式 (5), (35) ならびに操り系の運動学, 動力学式 （17），(29）を式（1），(2）に示す線形相補性問題に帰着させる.

まず, 式 (5)，（35）をもとに，相補性制約式（1）の導出に ついて述べる.すべての接触点について式（5）をまとめると

$$
\left.\begin{array}{ccc}
\boldsymbol{a}_{N R} \cdot \boldsymbol{f}_{N R}=0, & \boldsymbol{a}_{N R} \geq \mathbf{0}, & \boldsymbol{f}_{N R} \geq \mathbf{0} \\
\boldsymbol{a}_{N S} \cdot \boldsymbol{f}_{N S}=0, & \boldsymbol{a}_{N S} \geq \mathbf{0}, & \boldsymbol{f}_{N S} \geq \mathbf{0}
\end{array}\right\}
$$

を得る.ここで, “.”は内積を, $\mathbf{0}$ はゼロベクトルを示す. 前 節で導入された非負変数の右上添え字,+- を $T, U$ 方向に関 してそれぞれ $\Pi_{T i}, \Pi_{U i}$ で表すと, 式 (35) は

$$
\begin{aligned}
& \left.\begin{array}{l}
a_{T R i}^{\Pi_{T i}} \Delta_{T i}^{\overline{\Pi_{T i}}}=0, \quad a_{T R i}^{\Pi_{T i}} \geq 0, \quad 0 \leq \Delta_{T i}^{\overline{\Pi_{T i}}} \leq \mu f_{N R i} \\
\Pi_{U i} \Delta_{U i}
\end{array}\right\}
\end{aligned}
$$

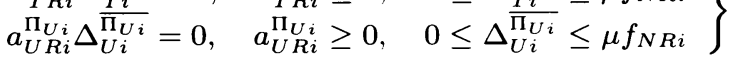

$$
\begin{aligned}
& \text { for } \Pi_{T i}, \Pi_{U i} \in\{+,-\}
\end{aligned}
$$

で表される. ただし, $\overline{\Pi_{T i}}, \overline{\Pi_{U i}}$ は $\Pi_{T i}, \Pi_{U i}$ の逆符号を示す. 式（37）をすべての転がり接触点についてまとめると

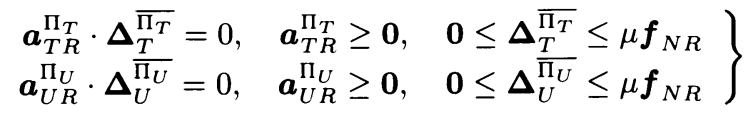

となる.ここで, ・ $\in\{T, U\}$ とすると

$$
\begin{aligned}
& \Pi_{\bullet} \in\left\{\Pi_{\bullet 1}, \Pi_{\bullet 2}, \cdots, \Pi_{\bullet n_{R}}\right\}
\end{aligned}
$$

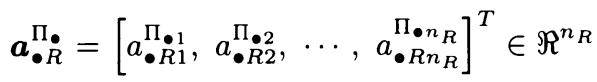

$$
\begin{aligned}
& \Delta_{\bullet}^{\Pi_{\bullet}}=\left[\Delta_{\bullet 1}^{\Pi_{\bullet 1}}, \Delta_{\bullet 2}^{\Pi_{\bullet} 2}, \cdots, \Delta_{\bullet n_{R}}^{\Pi_{\bullet} n_{R}}\right]^{T} \in \Re^{n_{R}}
\end{aligned}
$$

式（36），（38）をまとめると式（1）に相当する相補性制的式

$$
\left[\begin{array}{c}
\boldsymbol{a}_{N S} \\
\boldsymbol{a}_{N R} \\
\boldsymbol{a}_{T R}^{\Pi_{T}} \\
\boldsymbol{a}_{U R}^{\Pi_{U}}
\end{array}\right]^{T}\left[\begin{array}{c}
\boldsymbol{f}_{N S} \\
\boldsymbol{f}_{N R} \\
\boldsymbol{\Delta}_{T}^{\bar{\pi}_{T}} \\
\boldsymbol{\Delta}_{U}^{\Pi_{U}}
\end{array}\right]=0,\left[\begin{array}{c}
\boldsymbol{a}_{N S} \\
\boldsymbol{a}_{N R} \\
\boldsymbol{a}_{T R}^{\Pi_{T}} \\
\boldsymbol{a}_{U R}^{\Pi_{U}}
\end{array}\right] \geq \mathbf{0},\left[\begin{array}{c}
\boldsymbol{f}_{N S} \\
\boldsymbol{f}_{N R} \\
\boldsymbol{\Delta}_{T}^{\Pi_{T}} \\
\boldsymbol{\Delta}_{U}^{\Pi_{U}}
\end{array}\right] \geq \mathbf{0}
$$

を得る。ただし， $\Delta_{T}^{\overline{\Pi_{T}}}, \Delta_{U}^{\overline{\Pi_{U}}}$ は，拘束条件

$$
\boldsymbol{\Delta}_{T}^{\overline{\Pi_{T}}} \leq \mu \boldsymbol{f}_{N R}, \quad \boldsymbol{\Delta}_{U}^{\overline{\Pi_{U}}} \leq \mu \boldsymbol{f}_{N R}
$$

を満たす。

次に, 式 (17)，(29）をもとに, 線形方程式 (2) の導出につ いて述べる.まず, 式 (17)，（29）を式 (5)，（35）で導入した非 負変数 $\left(f_{N R i}, f_{N S i}, a_{N R i}, a_{N S i}, a_{T R i}^{+}, a_{T R i}^{-}, a_{U R i}^{+}, a_{U R i}^{-}\right.$, $\left.\Delta_{T i}^{+}, \Delta_{T i}^{-}, \Delta_{U i}^{+}, \Delta_{U i}^{-}\right)$を用いて表す。転がり接触点に作用 する各接触接線力 $f_{T R i}, f_{U R i}$ は, 式 (32) に示す接触集合 $S_{1}, S_{2}$ のいずれかに属しているので, 式 (29) の $f_{T R i}, f_{U R i}$ を $f_{T R i}^{+}, f_{T R i}^{-}, f_{U R i}^{+}, f_{U R i}^{-}$を用いて表すと

$$
\begin{aligned}
& \boldsymbol{M} \dot{\boldsymbol{V}}= \sum_{i=1}^{n_{R}}\left(\boldsymbol{W}_{N R i} f_{N R i}+\boldsymbol{W}_{T R i}^{\Pi_{T i}} f_{T R i}^{\Pi_{T i}}+\boldsymbol{W}_{U R i}^{\Pi_{U i}} f_{U R i}^{\Pi_{U i}}\right) \\
&+\sum_{i=1}^{n_{S}} \boldsymbol{W}_{\mu S i} f_{N S i}+\boldsymbol{h} \\
& \text { for } \quad \Pi_{T i}, \Pi_{U i} \in\{+,-\}
\end{aligned}
$$

となる. 式 (41) は, 各転がり接触点の $T, U$ 方向の接触力が, それぞれ接触集合 $S_{1}$ または $S_{2}$ に属した際の操り系の運動方 程式を表す。ここで, $\boldsymbol{W}_{T R i}^{+}=\boldsymbol{W}_{T R i}, \boldsymbol{W}_{T R i}^{-}=-\boldsymbol{W}_{T R i}$ であ る. $\boldsymbol{W}_{U R i}^{+}, \boldsymbol{W}_{U R i}^{-}$も同様に定義される.

式 (33) の $f_{T R i}^{+}, f_{T R i}^{-}, f_{U R i}^{+}, f_{U R i}^{-}$を式 (41) に代入し, スラック変数 $\Delta_{T i}^{+}, \Delta_{T i}^{-}, \Delta_{U i}^{+}, \Delta_{U i}^{-}$を用いて表すと

$$
\begin{aligned}
\boldsymbol{M} \dot{\boldsymbol{V}}= & \sum_{i=1}^{n_{R}}\left[\left(\boldsymbol{W}_{N R i}+\mu\left(\boldsymbol{W}_{T R i}^{\Pi_{T i}}+\boldsymbol{W}_{U R i}^{\Pi_{U i}}\right)\right) f_{N R i}\right. \\
& \left.-\boldsymbol{W}_{T R i}^{\Pi_{T i}} \Delta_{T i}^{\Pi_{T i}}-\boldsymbol{W}_{U R i}^{\Pi_{U i}} \Delta_{U i}^{\Pi_{U i}}\right]+\sum_{i=1}^{n_{S}} \boldsymbol{W}_{\mu S i} f_{N S i} \\
& +\boldsymbol{h} \quad \text { for } \quad \Pi_{T i}, \Pi_{U i} \in\{+,-\}
\end{aligned}
$$

を得る. 式 (42)をまとめると, 最終的に操り系の運動方程式は, 


$$
\boldsymbol{M} \dot{\boldsymbol{V}}=\boldsymbol{W}_{\mu\left(\Pi_{T}, \Pi_{U}\right)}\left[\begin{array}{c}
\boldsymbol{f}_{N S} \\
\boldsymbol{f}_{N R} \\
\boldsymbol{\Delta}_{T}^{\Pi_{T}} \\
\boldsymbol{\Delta}_{U}^{\Pi_{U}}
\end{array}\right]+\boldsymbol{h}
$$

で表される.ここで，・ $\in\{T, U\}$ とすると

$$
\begin{aligned}
& \boldsymbol{W}_{\bullet R}^{\Pi \bullet}= {\left[\boldsymbol{W}_{\bullet R 1}^{\Pi_{\bullet 1}}, \boldsymbol{W}_{\bullet R 2}^{\mathrm{II} \cdot 2}, \cdots, \boldsymbol{W}_{\bullet R n_{R}}^{\Pi_{\bullet n_{R}}}\right] \in \Re^{\left(6+n_{\theta}\right) \times n_{R}} } \\
& \boldsymbol{W}_{\mu\left(\Pi_{T}, \Pi_{U}\right)}=\left[\boldsymbol{W}_{\mu S}, \boldsymbol{W}_{N R}+\mu\left(\boldsymbol{W}_{T R}^{\Pi_{T}}+\boldsymbol{W}_{U R}^{\Pi_{U}}\right),\right. \\
&\left.\quad-\boldsymbol{W}_{T R}^{\Pi_{T}},-\boldsymbol{W}_{U R}^{\Pi_{U}}\right] \in \Re^{\left(6+n_{\theta}\right) \times\left(3 n_{R}+n_{S}\right)}
\end{aligned}
$$

である．ただし，転がり接触または滑り接触の一方の接触モー ドのみしか存在しない場合, 存在していない接触モードに対応 する要素が式 (43) の右辺第 1 項から除かれる.

同様に, 操り系の運動拘束条件式（17）を非負変数を用いて表 す. 接線方向の各相対加速度 $a_{T R i}, a_{U R i}$ は, それぞれ接触集合 $S_{1}, S_{2}$ のいずれかに属しているので, 式 (17) の $a_{T R i}, a_{U R i}$ を $a_{T R i}^{+}, a_{T R i}^{-}, a_{U R i}^{+}, a_{U R i}^{-}$を用いて表すと

$$
\left[\begin{array}{c}
\boldsymbol{a}_{N S} \\
\boldsymbol{a}_{N R} \\
\boldsymbol{a}_{T R}^{\Pi_{T}} \\
\boldsymbol{a}_{U R}^{\Pi_{U}}
\end{array}\right]=\boldsymbol{W}_{\left(\Pi_{T}, \Pi_{U}\right)}^{T} \dot{\boldsymbol{V}}+\dot{\boldsymbol{W}}_{\left(\Pi_{T}, \Pi_{U}\right)}^{T} \boldsymbol{V}
$$

のように記述できる.ここで，

$$
\begin{aligned}
\boldsymbol{W}_{\left(\Pi_{T}, \Pi_{U}\right)}=\left[\boldsymbol{W}_{N S}, \boldsymbol{W}_{N R}, \boldsymbol{W}_{T R}^{\Pi_{T}},\right. & \left.\boldsymbol{W}_{U R}^{\Pi_{U}}\right] \\
& \in \Re^{\left(6+n_{\theta}\right) \times\left(3 n_{R}+n_{S}\right)}
\end{aligned}
$$

式 (39) に示すように, $\boldsymbol{a}_{T R}, \boldsymbol{a}_{U R}$ と $\boldsymbol{\Delta}_{T}, \boldsymbol{\Delta}_{U}$ は互いに逆 の符号をもつ. そこで, 式 $(43)$ の符号を $\overline{\Pi_{T}}, \overline{\Pi_{U}}$ に書き直 してから $\dot{\boldsymbol{V}}$ について解き, 式 (44) に代入すると, 最終的に 式 (2) に相当する線形方程式

$$
\left[\begin{array}{c}
\boldsymbol{a}_{N S} \\
\boldsymbol{a}_{N R} \\
\boldsymbol{a}_{T R}^{\Pi_{T}} \\
\boldsymbol{a}_{U R}^{\Pi_{U}}
\end{array}\right]=\boldsymbol{A}\left[\begin{array}{c}
\boldsymbol{f}_{N S} \\
\boldsymbol{f}_{N R} \\
\boldsymbol{\Delta}_{T}^{\overline{\Pi_{T}}} \\
\boldsymbol{\Delta}_{U}^{\overline{\Pi_{U}}}
\end{array}\right]+\boldsymbol{b}
$$

が得られる。ここで,

$$
\begin{aligned}
\boldsymbol{A} & =\boldsymbol{W}_{\left(\Pi_{T}, \Pi_{U}\right)}^{T} \boldsymbol{M}^{-1} \boldsymbol{W}_{\mu\left(\overline{\Pi_{T}}, \overline{\Pi_{U}}\right)} \\
\boldsymbol{b} & =\boldsymbol{W}_{\left(\Pi_{T}, \Pi_{U}\right)}^{T} \boldsymbol{M}^{-1} \boldsymbol{h}+\dot{\boldsymbol{W}}_{\left(\Pi_{T}, \Pi_{U}\right)}^{T} \boldsymbol{V}
\end{aligned}
$$

である. 以上より, 三次元操り系の剛体接触問題は, 式 (40) を 拘束条件とし式 (39)，（45）で表される線形相補性問題に帰着 される相補性モデルで表すことができた。

\section{3 相補性モデルに対する解法}

相補性モデル式 (39)，（40），(45）に対して, 力学的に実現 可能な接触集合の組み合わせは未定である. 本節では, ある接 触集合の組み合わせ $\Pi_{T}, \Pi_{U}$ を仮定したとき, 導出した相補性 モデルに対して, 加速度, 接触力, 接触モード遷移を求める解 法について述べる.なお，接触集合の決定および解の妥当性を 含めた動力学計算アルゴリズムについては次節で述べる. 操り
系の各瞬間の把握状態（対象物, 多指ハンドの位置・速度）と 動力学パラメータが既知ならば, 式 (46) から行列 $\boldsymbol{A}$ を得る. 一方, 式 (47) のベクトル $\boldsymbol{b}$ は, 式 $(28)$ のベクトル $\boldsymbol{h}$ を含 むことから，関節駆動トルクを与えることで定まる．したがっ て, 式（40）を拘束条件として，式（39），(45）を線形相補性 問題の解法として知られるレムケ法 [5] を用いて解くことによっ て, 相対加速度 $a_{N S i}, a_{N R i} ， a_{T R i}, a_{U R i}$ および接触法線力 $f_{N S i}, f_{N R i}$ とスラック変数 $\Delta_{T i}, \Delta_{U i}$ を求めることができる. さらに，スラック変数の解を式 (33) に代入すると転がり接触 点の接触接線力 $f_{T R i}, f_{U R i}$ が得られる. 同様に, 滑り接触点 の接触接線力 $f_{T S i}, f_{U S i}$ は, 解 $f_{N S i}$ を式 (6) に代入して求 めることができる. 操り系の加速度 $\dot{\boldsymbol{V}}$ は，ここで得られた接 触力の解を式 (29) に代入することで導出できる.

さて，2.1節で示したように，クーロン摩擦モデルを仮定する と, 2 剛体間における転がりと滑りの接触状態は，接触点の並進 方向の相対運動の状態（接線方向相対速度の有無）で区別される. したがって, 接触モードの遷移は, 相補性モデル式 (45) を解 いて得られる並進方向の相対加速度 $a_{N S i}, a_{N R i}, a_{T R i}, a_{U R i}$ の值によって以下のように分類することができる.

(a) 転がり接触

（a1）転がり接触 — 転がり接触

$$
a_{N R i}=a_{T R i}=a_{U R i}=0
$$

（a2）転がり接触 —滑り接触

$$
a_{N R i}=0, a_{T R i}^{2}+a_{U R i}^{2} \neq 0
$$

（a3）転がり接触 —接触離脱

$$
a_{N R i} \neq 0
$$

（b）滑り接触

（b1）滑り接触 $\longrightarrow$ 滑り接触
$a_{N S i}=0$

（b2）滑り接触 $\longrightarrow$ 接触離脱

$$
a_{N S i} \neq 0
$$

なお, 滑り接触から転がり接触の遷移は, 接触接線方向の相 対速度が零であるかどうかで決定される。

\section{4 動力学唯一性と動力学計算アルゴリズム}

任意の関節駆動トルクの作用に対して力学的に実現可能な唯 一な加速度, 接触力, 接触モード遷移が定まる操り系モデルを 動力学的唯一であると定義する. 操り系の動力学や制御のシミュ レーションを行う場合, 操り系モデルが各瞬間で動力学的唯一 であることが要求される．本相補性モデルを用いるには，力学 的に実現可能な接触集合の組み合わせがあらかじめ既知でない こと，そして線形相補性問題は一般に式（45）の任意のべクト ルbに対して相補性モデルが唯一解をもつとは限らないこと [4] を考慮しなければならない．本節では，本モデルの動力学的唯 一性と動力学計算アルゴリズムについて述べる。

各転がり接触点の $\mathrm{T}, \mathrm{U}$ 方向の接触力, 相対加速度は, 接 触集合 $S_{1} ， S_{2}$ のいずれかに属するので，各転がり接触点 では 4 通りの接触集合の組み合わせの候補 $\left(\Pi_{T i}, \Pi_{U i}\right)=$ $\{(+,+),(+,-),(-,+),(-,-)\}$ が考えられる. 操り系モデ ルが動力学的唯一であるならば, 関節駆動トルクの作用に対し て力学的に実現可能な唯一な接触集合の組み合わせが存在する. ここでは，まず前節で述べた解法に基づいて，すべての接触集 合の組み合わせ候補について相補性モデル (39), (40), (45) 
を解く。そして, 唯一の接触集合の組み合わせに対して, 実行 可能解が存在するかどうかを調べる。もし存在する場合, その 接触集合と実行可能解を動力学的唯一を満たす候補とする.

しかし, 式 (45) のベクトル b は, 関節駆動トルクの関数に なっていることから，たとえ実行可能解が発見できたとしても， その相補性モデルが任意の関節駆動トルクの值に対して常に唯 一の解をもつとは限らない。 そのような場合, そのモデルは動 力学的唯一とならないため, その実行可能解は力学的意味をも たない。ここでは, 相補性モデルが動力学的唯一であることを 検証するために, 線形相補性問題の唯一解の存在性に関して知 られている以下の定理（文献 [4] 定理 3.3.7）を用いる.

[定理] 線形相補性問題（1），(2)において，任意のベクト ル $\boldsymbol{b}$ に対して唯一解 $x_{i}, y_{i}$ の組が存在するたの必要十分条件 は, 行列 $\boldsymbol{A}$ が $P$ マトリクス (主小行列式がすべて正となる行 列. 文献 [4] 定理 3.3.4）となることである.

式（46）に示す行列 $\boldsymbol{A}$ は，操り系の接触モード, 動力学パラ メータ, 各瞬間のコンフィギュレーションに依存するので, 相補 性モデルが必ずしも任意の関節駆動卜ルクに対して唯一解をも たないことが分かる。また，パワーグラスプのように滑りを許 さない接触点が多くなると, 式 (46) の行列 $\boldsymbol{W}_{\left(\Pi_{T}, \Pi_{U}\right)}^{T}$ の行 が線形独立でなくなるので, 行列 $\boldsymbol{A}$ が $P$ マトリクスにならず, 当然のことながら操り系モデルは唯一解をもたなくなる。ここ で, 上の定理を適用し, 動力学的唯一な解を導出するためのア ルゴリズムについてまとめる。 上述のように実行可能解と唯一 な接触集合の候補を決定した後, その候補に対応する相補性モ デルの行列 $\boldsymbol{A}$ が $P$ マトリクスであるかどうかを調べる。もし $P$ マトリクスであるならば，その実行可能解を動力学的唯一を 満足する解とみなす。

\section{4. 数值シミュレーション}

本章では，提案した相補性モデルに基づく解法を実際の多指 ハンドによる操りの動力学計算に適用しその有用性を示すとと もに, 接触モード遷移が, 摩擦係数, 関節駆動トルクの大きさ によって，どのように変化するかを数值シミュレーションによ り示す。

数值シミュレーションの例として簡単のため, Fig. 8 に示す ように, 2 関節 2 本指による楕円形対象物の垂直面内操りを考 える.この場合, 各転がり接触点では 2 通りの接触集合の組み 合わせ $\{+,-\}$ を考えればよい. 基準座標系 $\Sigma_{B}$ を両指第一関 節軸を結ぶ線分の中点, 対象物座標系 $\Sigma_{O}$ を対象物重心に設置 する. $\Sigma_{O}$ の原点位置は $\Sigma_{B}$ の $z$ 軸上の $z=-0.3[\mathrm{~m}]$ にあ $\eta$, 対象物の長軸が $\Sigma_{B}$ の $x$ 軸と平行な姿勢にある. 初期状態 では, 対象物は両指の第 2 リンクと接触し, 多指ハンドに対し て静止しているので, 各接触点は転がり接触の運動拘束を満足 している. 楕円形対象物の長軸, 短軸の長さおよび質量はそれ ぞれ $0.37,0.30[\mathrm{~m}], 3.0[\mathrm{~kg}]$, リンク長および質量はそれぞれ $0.3[\mathrm{~m}], 0.5[\mathrm{~kg}]$, 両指第一関節軸間距離 $0.2[\mathrm{~m}]$ とする. 両指 の第 1,2 関節角度は, $\Sigma_{B}$ の $x$ 軸に対して図中矢印の回転向 きに $45.0,87.7[\mathrm{deg}]$ となる.

ここでは, Fig. 8 に示す指 1,2 の第 2 関節の関節駆動トルク $\tau_{1}, \tau_{2}$ をパラメータとして, 関節駆動トルクを与えた瞬間に発 生する接触モードの遷移を数值シミュレーションにより検証す

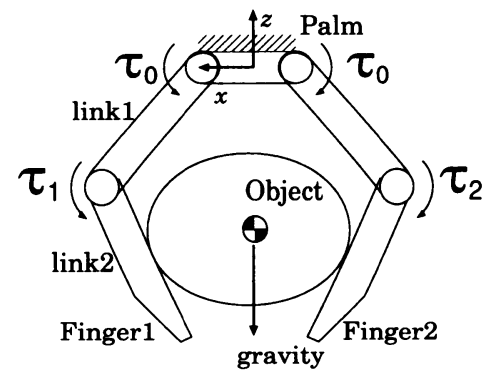

Fig. 8 Simulation model

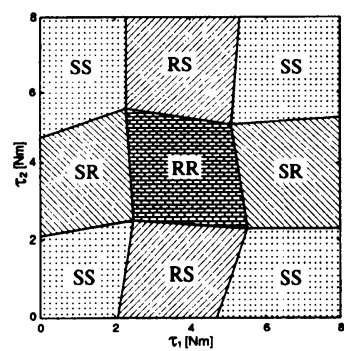

(a) $\mu=0.2$

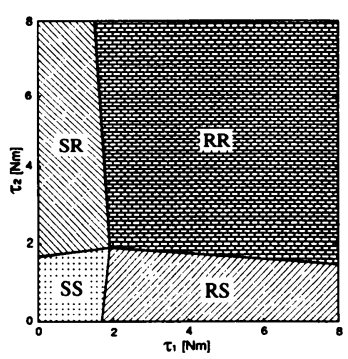

(b) $\mu=0.4$
Fig. $9 \tau$-space for $\mu=0.2$ and 0.4

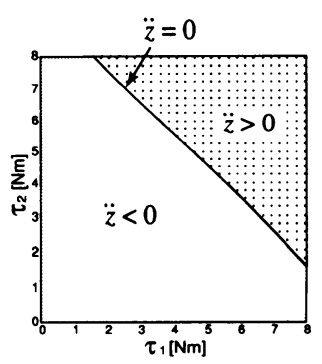

(a)

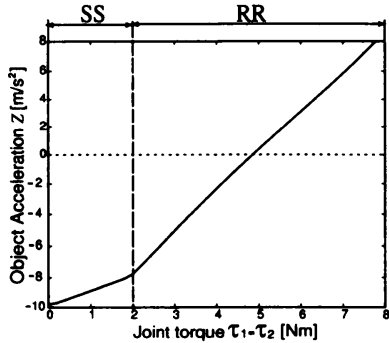

(b)
Fig. 10 Relation between joint torques and object acceleration in the $z$ direction for $\mu=0.4$. Fig.(a) shows the regions of object acceleration generated for applied joint torques, $\tau_{1}$ and $\tau_{2}$. Fig.(b) shows the generated object acceleration for $\tau_{1}=\tau_{2}$

る.な挹, 両指の第 1 関節には, $\tau_{0}=2.5[\mathrm{Nm}]$ の関節駆動トル クを与える。関節駆動トルクの向きは図中の矢印向きを正とす る.Fig.9(a), (b) に，それぞれ摩擦係数 $\mu=0.2,0.4$ に対す る接触モード遷移のシミュレーション結果（ここで $\tau$-space と 呼ぶ)を示す. ただし, 3.4 節の定理に基ついて, 動力学的唯一 性を満たす解であることが確認されている. 図中, $R S$ は関節駆 動トルクの負荷によって, 指 1,2 の接触点がそれぞれ転がり接 触, 滑り接触へ遷移することを示している．RR, $S R, S S$ も同 様に定義する，なお，関節駆動トルクがゼロのとき，接触は離脱 する. 本シミュレーションモデルは Fig. 8 に示すように，接触 点配置が対称になっていることから， $\tau$-space 上の接触モード 領域も対称となる。このシミュレーション結果は, (i) 与えられ る関節駆動トルクの大きさによって発生する接触モードは変化 する, (ii) 摩擦係数を大きくすると, 転がり接触へ遷移する領域 は大きくなることを示している.Fig.10(a)は, Fig. 9(b)の 例に対して，関節駆動トルクを作用したときに発生する $z$ 軸方 
向の対象物加速度符号の領域を表している. Fig. 10 (b) は, 特 に関節駆動トルクが $\tau_{1}=\tau_{2}$ の場合に発生する $z$ 軸方向の対 象物加速度を示している. Fig. 10 (a), (b) は, (i) 関節駆動卜 ルクの増加につれて, 対象物を $+z$ 方向に持ち上げる加速度が 発生すること, (ii) $\tau$-space 上のたとえ同じ接触モード領域で あっても，作用する関節駆動トルクの大きさによって発生する 加速度の符合が異なることを示している。

\section{5. おわりに}

本論文では, 接触モードの遷移を推定できる相補性モデルに 基づく三次元剛体操り系の順動力学モデルおよび動力学唯一性 を満たす解を導出する動力学計算アルゴリズムを提案した。さ らに提案した相補性モデルを多指ハンドによる操りの動力学シ ミュレーションに適用し，その有用性を示した。

さて, 提案した相補性モデルが現実の物理現象と一致してい るかどうかという問題は, 今後物理実験を行って検証していく 必要がある。この検証実験や実際の操り制御を行うためには, 接触状態の正確な情報を得るための分布型の触覚・覚センサ の開発というハード面の問題も解決しなければならないと考え る.これらの問題も含めて, 将来の課題とする. ところで, 相 補性モデルが動力学的唯一でない場合, その解は力学的な意味 をもたない。この問題に対して, 筆者らは相補性モデルとコン プライアンスモデルを統合した動力学計算アルゴリズムを提案 した [15]. 相補性モデルが動力学的唯一でないときのみコンプ ライアンスモデルを用いて順動力学計算を行い, 全体的に計算 コストが小さくロバストな動力学シミュレータを実現している. 本アルゴリズムでは， $4^{n_{R}}$ (三次元操り) または $2^{n_{R}}$ (二次元 操り）と㧍りの接触集合の組み合わせを考虑しなければならな い.よって，転がり接触点数が多くなるにつれて計算コストが 増大する. 力学的に実現不可能な接触集合の組み合わせを簡単 に特定できるならば [12], そのような組み合わせをあらかじめ 除くことによって，探索回数を減らすことが可能である。これ は将来の課題とする。本論文では関節駆動トルクの作用によっ て新たな接触が生じない操り系を仮定した。接触の発生は力学 的に衝突現象と考えられる. 衝突を考慮した操り系の相補性モ デルの構築は将来の課題とする。

\section{参 考 文 献}

[1] B. Brogliato: Nonsmooth Mechanics. Springer, 1999.

[2] A.A. Cole, J.E. Hauser and S.S. Sastry: "Kinematics and Control of Multifingered Hands with Rolling Contact," IEEE Transactions on Aotomatical Control, vol.34, no.4, pp.398-404, 1989.
[3 ] A.A. Cole, P. Hsu and S.S. Sastry: "Dynamic Control of Sliding by Robot Hands for Regrasping," IEEE Transactions on Robotics and Automation, vol.8, no.1, pp.42-52, 1992.

[4] R.W. Cottle, J. Pang and R.E. Stone: The Linear Complementarity Problem. Academic Press, 1992.

[5] 茨木, 福島：FORTRAN 77 最適化プログラミング. 岩波書店, 1991.

[6] H.S. Howard and V. Kumar: "A Miminum Principle for the Dynamic Analysis of Systems with Frictional Contacts," IEEE International Conference on Robotics and Automation, pp.437442, 1993.

[7] K.H. Hunt and F.R.E. Crossley: "Coefficient of restitution interpreted as damping in vibroimpact," ASME Journal of Applied Mechanics, vol.42, Series E, pp.440-445, 1975.

[8] 金子, 東森, 辻：“包み込み把握の遷移安定性”, 日本ロボット学会誌, vol.16, no.5, pp.712-720, 1998

[9 9 P.R. Kraus, A. Fredriksson and V. Kumar: "Modeling of Frictional Contacts for Dynamic Simulation," IROS 1997 Workshop on Dynamic Simulation: Methods and Applications, 1997.

[10] P. Lötstedt: "Coulomb Friction in Two-Dimensional Rigid Body Systems," Zeitschrift Für Angewandte Mathematik und Mechanik, vol.61, pp.605-615, 1981

[11] M.A. Nahon and J. Angeles: "Real-time force optimization in parallel kinematic chains under inequality constraints," IEEE Transaction on Robotics and Automation, vol.8, no.4, pp.439450, 1992

[12] 小俣，永田：“多指ハンドによるパワーグラスプの力学的特性”, 日本 ロボット学会誌, vol.13, no.4, pp.525-531, 1995.

[13] F. Pfeiffer and C. Glocker: Multibody Dynamics with Unilateral Contacts (Wiley Series in Nonlinear Science). John Wiley \& Sons, 1996.

[14] N. Sarker, X. Yun and V. Kumar: "Dynamic Control of 3-D Rolling Contacts in Two-Arm Manipulation," IEEE Transactions on Robotics and Automation, vol.13, no.3, pp.364-376, 1997.

[15] P. Song, M. Yashima and V. Kumar: "Dynamic Simulation for Grasping and Whole Arm Manipulation," IEEE International Conference on Robotics and Automation, pp.1082-1087, 2000.

[16] P. Song, M. Yashima and V. Kumar: "Dynamics and Control of Whole Arm Grasps," IEEE International Conference on Robotics and Automation, pp.2229-2234, 2001.

[17] J.F. Trinkle, J.M. Abel and R.P. Paul: "An Investigation of Frictionless Enveloping Grasping in the Plane," The International Journal of Robotics and Research, vol.7, no.3, pp.33-51, 1988.

[18] J.C. Trinkle, J.S. Pang, S. Sudarsky and G. Lo: "On Dynamic Multi-Rigid-Body Contact Problems with Coulomb Friction," Z. angew. Math. Mech, vol.77, no.4, pp.267-279, 1997.

[19] 八島，山口：“接触モードのスイッチングに基づく多指ハンドによる 包み込み把握の運動計画—ハイブリッドシステムの運動計画—”, 計 測自動制御学会論文集, vol.39, no.2, pp.150-158, 2003.

[20] 横小路, 坂本, 吉川：“ソフトフィンガー型の多指ハンドによる物体 の操りのための接触点における摩擦モーメント補償”, 日本ロボット 学会誌, vol.17, no.6, pp.876-886, 1999.

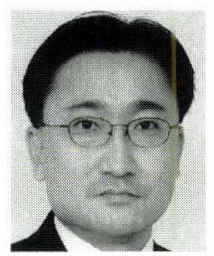

八島真人 (Masahito Yashima)

1961 年 10 月 25 日生. 1987 年早稲田大学大学院 理工学研究科機械工学専攻修士課程修了. 1993 年 東北大学大学院工学研究科機械工学第二専攻博士課 程修了. 1987 1989 年 (株) 東芝勤務. 1993 年防 衛大学校助手, 講師を経て, 1998 年同助教授, 現 在に至る。1999 2000 年米国ペンシルバニア大学 客員研究員.ロボットハンドの力学と運動制御の研究に従事. 博士 (工学). 計測自動制御学会, 日本機械学会, IEEE どの会員.

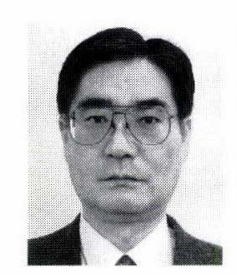

山口秀谷 (Hideya Yamaguchi)

1950 年 8 月 29 日生. 1980 年東北大学大学院工学 研究科博士課程修了. 1981 年東北大学工学部助手, 1985 年防衛大学校講師, 助教授を経て, 機械シス テム工学科教授，現在に至る，振動制御の研究に従 事. 工学博士. 日本機械学会などの会員.

(日本ロボット学会正会員)

(日本ロボット学会正会員) 